Article

\title{
Why Prostitution Policy (Usually) Fails and What to Do about It?
}

\author{
Hendrik Wagenaar \\ Department of Urban Studies and Planning, The University of Sheffield, Sheffield S10 2TN, UK; \\ h.wagenaar@sheffield.ac.uk \\ Academic Editor: Leslie Jeffrey \\ Received: 13 March 2017; Accepted: 20 April 2017; Published: 28 April 2017
}

\begin{abstract}
This article describes and discusses the results of two comparative studies of prostitution policy in Europe that are complementary in their design and methodology. One is a comparison of 21 countries using a most different systems design; the other an in-depth comparison of Austria and The Netherlands, using a most similar systems design. The two studies found a remarkable continuity in the inherent approach to the regulation of prostitution and its effects. Despite differences in political regime, administrative organization, and national cultures, since the middle of the 19th century, the purpose of prostitution policy has been to impose strict controls on sex workers and to a lesser extent their work sites. The effects of this approach have been disappointing: despite rhetorical claims to the contrary the control of sex workers has no discernable effect on the prevalence of prostitution in society. The effects of policies aimed at control are mostly negative in that they corrode the human and labor rights of sex workers. The article discusses several challenges to the regulation of prostitution (such as its deeply moral nature and the lack of precise and reliable data) as well a number of other important outcomes (such as the importance of local policy implementation for the effects of regulation). The article concludes with the empirically substantiated suggestion that a form of collaborative governance in which sex worker advocacy organizations participate in the design and implementation of prostitution policy offers real prospects for an effective and humane prostitution policy.
\end{abstract}

Keywords: prostitution; trafficking; public policy; sex workers; human rights; labor exploitation; labor rights; collaborative governance

\section{Introduction ${ }^{1}$}

Policy making, the concerted efforts by governments to regulate prostitution through laws, bylaws, licenses, prohibitions, inspections, enforcement and other policy instruments, is underrepresented in the academic literature on prostitution (Wagenaar et al. 2017, chap. 1). This is despite the fact that since roughly the beginning of the 19th century, in the wake of the consolidation of the Western nation state, prostitution as a social phenomenon is entangled with the efforts of authorities to prohibit, contain or regulate it (Corbin 1990; Gibson 1986; Walkowitz 1980). In the advanced Western democracies, prostitution, in all its manifestations, is deeply entangled with the state. The article presents the results and conclusions from two unique research projects on prostitution policy in Europe (Wagenaar et al. 2017; Jahnsen and Wagenaar 2017). The first was an in-depth comparison of the regulation of the sex trade in Austria and The Netherlands since 2000 that offered an analysis of

1 This article is based on my previous article in the book Assessing Prostitution Policies in Europe, which is to be published in Autumn 2017 (Wagenaar 2017). The text of this article is expanded in some areas and condensed in others. 
the multi-level nature of prostitution governance. The second was a comparison of the prostitution policies of 21 European countries over the past 150 years. ${ }^{2}$ The two studies represent complementary research strategies, with one highlighting the different and the other the similar features that account for the observed policy outcomes (Landman 2000, p. 70). Together the two studies present a robust set of data about the structure, process and outcomes of policy making in the domain of prostitution across a wide range of European countries and a century and half of policy making. The two-country comparison is a so-called most similar systems design (MSSD). The scientific rationale of a MSSD is that, when most independent variables are held constant, differences in the dependent variable are explained by those independent variables that do differ (Landman 2000, p. 71). ${ }^{3}$ The 21-country study on the other hand functions as a most different systems design (MDSD). Although we did not collect the data ourselves, the country profiles, prepared by local experts, were all written according to the same format. The basic idea of a MDSD is it takes countries with different variables within them and tries to figure out why the outcomes between them are roughly similar (Landman 2000, p. 71). Taken together the two studies constitute a unique, robust body of evidence, both synchronic and diachronic, about the process and effects of current approaches to prostitution policy in Europe.

What were the outcomes of the two studies? In broad-brush strokes, despite considerable differences in political regime, administrative organization, and national cultures, we observed the following broad patterns. From the mid-19th century onward the authorities of all countries under study attempted to control and regulate prostitution. This urge to control takes the form of prohibiting prostitution, as well as its commercial exploitation or, when allowed, of imposing stringent conditions on the location and operation of sex businesses. The state's desire for control is overwhelmingly aimed at (female) sex workers; through their sequestration (by quarantining them in separate neighborhoods or buildings, by prohibiting their freedom of movement), by imposing regimes of medical inspection, by subjecting sex workers to an array of more or less coercive regulations and supervisions, by constraining their entry and labor rights. Tackling the social 'problem' of prostitution has required the mobilization of considerable resources at all levels of government: financial, organizational, administrative, legal, diplomatic (in negotiating international treaties), intellectual (by financing research) and ideological. Yet, despite these resources, for over a century and half the regulation of prostitution has been largely ineffective. Despite optimistic rhetoric to the contrary no country had succeeded in significantly reducing the number of sex workers, let alone eradicating prostitution from society altogether. Throughout the 150 years every country under study had a prostitution industry, even in times when it was strictly prohibited. ${ }^{4}$ Regulation did have effects but these overwhelmingly amounted to an erosion of the human, civil and labor rights of sex workers, often resulting in various forms of labor exploitation. The more fine-grained comparison between Austria and The Netherlands showed how even countries that legalized and (partially) decriminalized the sex trade, gradually drifted towards more repressive measures in the implementation phase of national

2 The countries are Albania, Austria, Belgium, Croatia, the Czech Republic, Denmark, England and Wales, Finland, France, Germany, Greece, Ireland, Italy, Malta, The Netherlands, Norway, Portugal, Romania, Slovenia, Spain, Sweden, and Switzerland. National experts provided a detailed description of prostitution policy in their country according to an identical template. The study also included profiles of EU Policy and the advocacy efforts of European sex workers organizations.

3 The two country comparison is a small $n$ study: a comparison of 2 countries with a largely similar regime of regulating the sex trade. Such a comparison does not allow the researcher to hold the independent variables constant, simply because there are too many of them; this is the problem of "Too Few Cases/Too Many Variables" that dogs so much social science research (Goggin 1986). The value of small $\mathrm{n}$ comparative studies must be sought in the rich contextual comparison. Or as Landman puts it: "The comparison to the researcher's own country is either implicit or explicit, and the goal of contextual description is either more knowledge about the nation studied, about one's own political system, or both" (Landman 2000, p. 5).

4 One could argue that these measures were effective in that they at least prevented the uncontrolled expansion of the sex trade. However, apart from the fact that it is almost impossible to prove a counterfactual, in those few instances where we have some empirical evidence, it always points in the direction of the absence of a strong demand factor. For example, religious political parties feared a large increase in foreign sex workers after Dutch parliament repealed the ban on brothels in 2000. That increase never materialized. Similarly, predicted increases in the number of sex workers (and trafficking) in the wake of large sports tournaments never materialized (Asmar 2014). 
legislation. In general, prostitution policy is prone to sudden reversals, unfortunately almost always to more repressive policy regimes. Policy making in the domain of prostitution is almost wholly driven by ideology. Precise and reliable data on even the most elementary parameters of prostitution (such as the number of sex workers in a particular locale) are lacking; whatever data are in circulation are unreliable and mostly subservient to ideological purposes. Policy changes, both progressive and repressive were almost exclusively based on changes in doctrine and/or political regime (Wagenaar et al. 2017; Jahnsen and Wagenaar 2017).

In this paper we will discuss these disappointing and disturbing outcomes in more detail. In Section 2 we will first discuss the particular challenges that regulating prostitution faces. In every domain, policy making faces specific challenges and it may very well be the case that these challenges prevent or constrain effective policy formulation and implementation. In Section 3 we will discuss our findings in more detail. In the final section I will present an alternative to the current control-driven approach in the regulation of prostitution. The introduction of the voice of sex workers in the design and implementation of prostitution policy through collaborative governance arrangements has been shown to result in effective and humane forms of regulation.

\section{Challenges to Prostitution Policy}

All policies have to confront domain-specific obstacles, impediments, demands and restrictions that shape and constrain the possibilities of concerted action. Arguably the biggest challenge of prostitution policy is its inherently moral nature. All policy making can be seen as the struggle over the realization of core societal values (Stone 1997), but in many of the advanced democracies of the West, prostitution is currently the subject of fierce debates and frenzied, often far-reaching, legislation. Prostitution is an archetypical example of morality politics (Bernstein 2010; Wagenaar and Altink 2012; Wagenaar et al. 2017, chap. 2). In the last two decades, however, a coalition of radical feminists and Christian and Social-Democratic politicians has captured the moral high ground in the debate about prostitution. By consistently portraying prostitution as an expression of male patriarchy (and therefore by definition coerced), sex workers as victims, and clients as "socially and morally tainted" (Chuang 2010, p. 1669), they argue successfully that prostitution should not have a place in civilized society. Prostitution, they argue is enabled by organized crime. This has resulted in the adoption in country after country, as well as in international agreements and by the EU parliament, of laws and recommendations to combat "slavery" and "trafficking". The instruments of choice are the prosecution of clients (in the expectation that this will ablate the "demand" for prostitution and send a signal to men that buying sex is morally unacceptable) and immigration law to guard national borders against traffickers and sex workers. Over and against this by now hegemonic position stands a loose coalition of progressive politicians, NGOs, academics and sex worker advocacy organizations that argue for the decriminalization of prostitution (Abel et al. 2010; Sanders and Campbell 2014). They favor a nonpenal approach to prostitution. Prostitution is considered a form of work that should be regulated with the instruments that apply to all small and mid-size businesses, such as labor, administrative and fiscal law. Criminal law only applies in cases of clearly illegal behavior such as rape, assault, or extortive forms of labor exploitation. As with every moral controversy, the political and public debate has all the qualities of a dialogue of the deaf.

The second challenge to prostitution policy is the almost complete lack of reliable data. For practical and conceptual reasons precise and reliable numbers are hard to obtain. Practical reasons include high mobility of sex workers and a difficult to access social milieu; conceptual reasons include ill-defined key categories such as "forced prostitution" or "trafficking" (Wagenaar et al. 2017; Weitzer 2015). As a result, not one of the 21 countries under study enjoyed precise and reliable data about prostitution to inform policy making. The first and the second challenge coalesce in the neo-abolitionist debate. Neo-abolitionists, inside and outside government, tend to use highly inflated numbers about the number of sex workers and victims of trafficking (Weitzer 2007); numbers which are then uncritically adopted by the media and the political class and function as political realities. 
The third challenge is the pervasive social stigma that is attached to prostitution. The effect of stigma is that it, deliberately and surreptitiously, shapes laws, regulations, practices, institutions and policies, and, in general, it results in the social marginalization of sex workers. Stigma expresses itself as the fear of moral and physical contagion and leads to the urge to control, contain or suppress prostitution (Pheterson 1996). Stigma also results in the breach or loss of human rights and civil liberties as a result of being deemed a prostitute. Wagenaar et al. show that many of those rights violations occur as a matter of fact, as business as usual, the side-effects of mundane administrative measures (Wagenaar et al. 2017, chap. 3).

The fourth challenge is the traditional close affiliation of prostitution and migration. Today, in Europe, prostitution migration is largely between countries, as prostitution is caught up in shifts in the global organization and distribution of capital, labor and citizenship and the large international migration streams that result from this. One effect of this interpenetration of prostitution and migration is the conflation in the public debate and, as a result, in public policy, of prostitution with trafficking (Davidson 2006; Weitzer 2007; Doezema 2010; Vance 2011). Only through close surveillance and control can 'traffickers' be discovered and their 'victims' rescued (Kempadoo 2012, p. xv). Wagenaar et al. (2017) argue that there is never a decisive closure to surveillance and control; the result is forms of hyper-regulation that attempt to control each and every aspect of the sex trade.

The final challenge is the primacy of the local in prostitution policy. Local policymaking, the myriad of rules, regulations and bylaws with which national policy approaches are translated into a workable policy design that can be effectively implemented, is essential in prostitution policy. National policy, no matter the direction and intensity of its moral ambition, needs to be translated into the mundane rules and procedures that transform it into a feasible administrative program. The discretionary autonomy that local officials exert in these matters can be discerned from the observation that in many countries local policy deviates, or even contradicts, national policy formulation.

The challenges of prostitution policy put both policymakers and analysts in a difficult position. Policy makers are entrusted with the task of designing rules and measures to regulate prostitution in the neighborhoods and streets of their locality, while these same phenomena are the outcome of transnational forces that are wholly beyond their control. Moreover, the laws, rules, policy instruments and organizational procedures that officials have at their disposal instantly become part of the larger, multi-level policy field and create a thicket of unintended consequences that fall outside the horizon of most officials and elected officials. Policy making in such circumstances can only be reactive, even when it presents itself as resolute and proactive, and, because of the intrinsic lack of reliable data and the pervasive stigma, myopic. In addition, there is a real risk that, as a result, it will be confused, latching onto the wrong aspects of the problem, in the process worsening instead of alleviating it. The five domain-specific challenges make prostitution policy a field "of coexisting and mutually interdependent factors" that produce unexpected and often unforeseen outcomes (Ison 2010, p. 32).

\section{Comparing Prostitution Policy in Europe}

In this section I present some of the key findings from the two studies. I discuss in succession: the continuity between historical and contemporary forms of regulation, the lack of precise and reliable data on the sex trade in virtually every European country, the importance of discourse in shaping prostitution policy, the importance of ancillary law for the position of sex workers, the confluence of prostitution and immigration policy and its negative effects on the position of sex workers, the importance of policy implementation, and the effects, intended and unintended, of prostitution policy.

First, by the end of the 19th century, in virtually all European countries the state had become deeply involved in regulating the sex trade. Most countries employed an intricate form of regulation that was known at the time as the French system. The United Kingdom (UK) and some other countries had laws and administrative arrangements that focused more exclusively on the prevention of the spread of contagious diseases. While the fear of sexually transmitted diseases (STDs), in particular syphilis and gonorrhea for which no effective cure was available at the time, was paramount in regulating 
prostitution, in all instances the laws, rules and ordinances reflected strong moral views on prostitution and sex workers, and usually included more than regular mandatory testing for STDs. Regulation was based on three principles, each of which aimed at containing and disciplining the prostitute: ${ }^{5}$ an enclosed milieu that contained prostitution and kept it out of sight, constant supervision by authorities, and the categorization of prostitutes (Corbin 1990, p. 9). Most regulatory regimes stipulated where prostitutes could work and where not, in what type of establishments, what clothes prostitutes should wear, but also how brothels should hide prostitutes from view (Albania, France, Greece, Malta, Norway) and how proprietors and clients were to behave towards prostitutes. In Norway: "This regulation included rules as to where prostitution could take place and what women involved in prostitution should wear, as well as mandatory curtains. These measures highlight how the regulation of prostitution did not only have public health as its purpose, but also regulation of public space and gender relations" (Jahnsen and Skilbrei 2017).

This form of regulating prostitution in the 19th and early 20th usually combined the criminalization of prostitution and prostitutes with a modicum of toleration (in France the enclosed space was fittingly called a "maison de tolerance"). Prostitutes were subject to extensive extra-judicial and custodial powers of the police. They could be arrested for minor rule infractions, banned from certain parts of the city, and, upon suspicion of harboring an STD locked up in a hospital for indefinite time. Even "bourgeois" women were arrested and had to prove that they were not in the sex trade. Then as now, respect for the human and civil rights of sex workers, if not entirely absent, was secondary to the goals and integrity of the regulatory arrangement. Reflecting the stigma of prostitution, the regulatory systems reinforced and sustained the stigma. At the same time, by integrating prostitution in the legal-administrative framework of the nascent nation states, prostitution became an activity that was, if not accepted, tolerated as an inevitable element of city life. ${ }^{6}$ We have to wait until the beginning of the 20th century for abolitionist and prohibitionist systems to gain a foothold.

For the purpose of understanding contemporary prostitution policy, it pays off to take a closer look at the moral and ideological underpinnings of the regulatory systems of the 19th century. First, and most obvious, the 19th century regulation of prostitution was expressive of the view of sexuality of the group in power: middle-class adult men and, to a lesser extent, women (Walkowitz 1980, p. 5). For example, medical inspection only applied to women and never to males, thereby extenuating whatever effectiveness it may have had (Walkowitz 1980, p. 3). But the ideological underpinning went much deeper than the imposition of a dominant male/bourgeois culture upon prostitutes. In the "regulationist project" (Corbin 1990) two 19th century middle class obsessions met: a preoccupation with the life of the poor and the underclass and a fascination with female sexuality. Originally, the regulationist project was rooted in a strong stereotype of the prostitute. Prostitutes were considered to be lazy, intemperate, profligate and immature, idle and impulsive (Corbin 1990, pp. 6-7). Her condition was a combination of innate temperament and family heritage. This combination of traits called out for supervision and surveillance. In addition, 19th century middle class reformers were obsessed with the lifestyle of the poor, in particular their alleged profligate sexual habits (Jones 2013). This obsession found epistemic expression in bringing the tools of the incipient social sciences in the form of categorization and survey projects to bear on the poor. It also resulted in ambitious programs of state intervention aimed at 'improving' slum housing (mostly by erasure) and 'moralizing' the poor (Jones 2013). The impetus of this middle class project was a deep-seated fear of insurrection and disorder, as well as contagion by loose morals. Around the turn of the century these fears would supplant geneticist images of the prostitute with fears of spreading disorder; regulationism was no longer seen as a sufficient remedy for containing prostitution and calls for abolitionism began to be heard (Corbin 1990; Walkowitz 1980). The upshot of this brief and simplified summary of the

I use the terminology that was common in the regulatory regimes of the 19th century.

Although we should not lose sight of the fact that the double standard that was inherent in the regulationist project secured middle class males sexual access to "fallen women" (Walkowitz 1980, p. 3). 
history of 19th century regulation is that the state's involvement in the regulation of prostitution represented a complex crosscurrent of larger images, ideas and sentiments about social class and sexual conduct. As (Corbin 1990, p. 24) summarizes it: "(T)he regulationist discourse had become the reflection and crossroads of all the bourgeois obsessions of the time." These "obsessions" were hidden beneath scientific theories and formal policy schemes whose overt aim was to understand and contain prostitution and improve the situation of the prostitute. Although the language has changed, the essential configuration of prostitution policy - a combination of obsessive attention that is driven by middle class obsessions with the poor, with migrants and with heterodox sexual conduct, a feverish desire by state authorities to intervene and regulate, the application of scientific instruments that give a gloss of authority to discursive images, and the ignoring of the rights of sex workers as the acceptable collateral effects of regulation-remains by and large unchanged. Under the veneer of national law, policy instruments, 'scientific' research reports commissioned by government agencies, and international agreements, contemporary prostitution policy still reflects the obsessions of the middle classes.

Second, prostitution policy takes place in a largely data free environment. In every country, regulatory schemes change, but rarely if ever because of new evidence or data. Regime change (the fall of a monarchy, the ascend of a communist regime), a new government, or the slow build-up of a different social discourse, are the driving forces behind the change in prostitution policy. We asked the authors of the country profiles to look into the availability of data on prostitution; not a single country can boast of precise and reliable statistics. In many countries (for example Romania, Croatia, Malta, Albania), with the exception of an occasional study by a local NGO, there simply are no data. In some cases, the police had collected data but these were seen as partial and unreliable. In other countries (Austria, Germany, The Netherlands) national agencies had tried to collect data but the authors of the profiles regarded these as unreliable. It has become more common here and there for the government to tender research on aspects of prostitution policy. In Norway, Germany, Denmark and The Netherlands, the introduction of major new policies (ranging from client criminalization to the repeal of brothels) has resulted in official evaluations. However, in Sweden research became a tool in the government's efforts to educate the world about the moral virtue of abolitionism (Dodillet and Östergren 2013). Where 19th century regulationism, in the service of supervision and control, bred a desire for knowledge about the prostitute (Corbin 1990, p. 16), the 20th century regulationist project has resulted in a contradictory epistemic impulse that can best be described as an indifference to knowing that masquerades as a rhetorical allegiance to scientific research. In only a few countries (Norway, Denmark, The Netherlands, Germany) has the historical knowledge-control nexus been mirrored by a comparable research industry, consisting mostly of privatized knowledge, non-academic research agencies operating on government contracts, which evaluate various aspects of contemporary regulatory arrangements.

Third, the driver of prostitution policy in virtually all countries under study is discourse. There are many definitions of discourse (Wagenaar 2011, chap. 6) but in this article I use it in the sense of the collective cognitive-normative framing of a particular social phenomenon. In the absence of reliable data on a social phenomenon, discourse determines policy making. In fact, the lack of evidence opens up a convenient free cognitive space upon which actors can project their ideology (Doezema 2010, p. 9). This is no different today than it was in the 19th century. In our times the dominant discourse is neo-abolitionism. In most European countries today, even countries such as The Netherlands that have officially legalized brothels, neo-abolitionism shapes the course of public policy. ${ }^{7}$ In the last few years countries such as France, Germany, and The Netherlands, which had legalized the sex trade, have adopted national laws that contain neo-abolitionist elements, such as client criminalization and the registration of sex workers; this in addition to the Nordic countries (with the exception of

7 In some countries such as Romania, Albania, Portugal, Italy and Spain prostitution is prohibited and criminalized. 
Denmark) and Ireland that already had variations on neo-abolitionist law. Switzerland and Austria are the European exceptions in this international trend. Switzerland employs a largely humane form of light-touch regulation, and Austria, being a federal state, shows a range of policies at the provincial level that are held together by a harm-reduction type of approach.

The effect of discourse, the relation between discourse and the regulationist project then and now, is complex. From one perspective the laws, bylaws, ordinances, administrative arrangements and officials that regulate prostitution are discourse; that is they are the organizational expression of the power elite's beliefs, images and sentiments towards prostitution. These arrangements and professional roles form the sedimentation of a society's attitudes and sentiments towards prostitution. For example, in the Romanian national debate on prostitution, an interesting distinction is made between victims of trafficking (who are regarded with sympathy and compassion) and sex workers who choose to work in the country (who are condemned and to whom the full stigma applies) (Danet 2017). This finds organizational expression in the content of sex, illiteracy and health education classes that focus on preventing trafficking. However, the relationship between discourse and policy is neither linear nor unidirectional. Discourse is rarely a monolithic, unassailable ideological bloc that exhaustively determines political, administrative and professional arrangements. In fact, regulatory schemes also shape, consolidate and give legitimacy to different elements of the reigning discourse, while resistance to such schemes shapes the arguments of their supporters. Some of the fast-changing, ever-evolving regulation that characterizes prostitution policy in many European countries must be seen as both the result of, and the impulse to, further articulate and extend the neo-abolitionist discourse on prostitution, in a utopian drive to eradicate prostitution from society, or at a minimum to control it strictly.

A fourth theme in national prostitution policy is the use of a wide range of laws to regulate prostitution. Laws that are specifically aimed at prostitution form only one aspect of the regulatory package. And in some countries, such as Italy or Spain, the law is so ambiguous about the legal status of prostitution that regulation almost wholly rests on ancillary law. In most countries immigration law is specifically employed to police borders and/or regulate-read: constrict—-the labor market for new (low income) immigrants, including sex workers. In addition, labor laws, social welfare, housing, and data protection laws are all mobilized to contain and restrict prostitution (Wagenaar et al. 2017, chap. 4). And this is just national-level law that does not take into account the hundreds of local ordinances and bylaws that are aimed at regulating prostitution.

For various reasons, an exclusive focus on national prostitution law would result in a misleading picture of the way government intervenes in the sex trade. By taking ancillary law (and local administrative measures) into account we observe that prostitution is much more heavily regulated than a focus on prostitution policy alone would suggest. In the spirit of 19th century regulationism, the national and local governments of most countries feel compelled to regulate almost every aspect of the sex trade, from the condition of sex facilities and the behavior of proprietors to the health and behavior of sex workers and the position of third parties. Immigration, labor and fiscal law determine the legality of (certain forms of) prostitution for certain national groups, the type of labor arrangement, the level of earnings, and the possibilities for social mobility. Zoning ordinances and municipal bylaws prescribe and restrict the locations that are available for prostitution. Public health laws single out sex workers as an elevated risk and subject them to often unnecessarily frequent testing. It is not just the direction but the sheer intensity of regulation that strikes the observer. In another interesting parallel to the 19th century regulatory project, it does not go too far to speak, in some cases such as The Netherlands, Austria or Sweden, of hyper-regulation (Corbin 1990, p. 24). A barrage of prostitution and ancillary law, in combination with a welter of local rules, programs and administrative arrangements are aimed at every aspect of the sex trade. The manifest policy goal is the fight against trafficking; the latent impulse is the stigma (and the associated fear of unbridled expansion and moral contagion) that is attached to prostitution and sex workers, in combination with the aversion to low income immigrants. An indication of the fear of losing control over prostitution can be found in the injunctions in many localities against home prostitution. Starting a small prostitution business, either 
alone or with a colleague, that advertises on the internet, is either prohibited or tied to so many onerous conditions that it becomes de facto impossible. Second, the opportunistic use of ancillary law and policy instruments interacts with discourse in that the latter determines the selection and interpretation of the first. For example, while dozens of laws and bylaws are mobilized to constrain prostitution, in almost none of the countries under study is labor law applied to improve labor relations and work conditions of sex workers. The authorities self-evidently consider prostitution a criminal, social and moral problem, not a labor issue. One of the unintended consequences of this ideological choice is that, despite the intensity of regulation, labor exploitation is still rampant in the sex trade (ICSRE 2016).

A fifth outcome of the two studies is that in virtually every European country migration and immigration law are central aspects of prostitution policy. In 'supply' countries such as Albania or Romania, migration and trafficking are dominant themes in the national discourse. However, despite the excessive attention to trafficking, neither of these two countries has made efforts to obtain reliable numbers or provide effective services to its victims. Danet concludes, for example, that despite considerable government attention to the issue of trafficking, "in Romania there is no centralized mechanism for the screening, identification and referral of trafficking victims and, in addition, there is no common methodology for the documentation of cases" (Danet 2017). In Albania official estimates of victims of trafficking working abroad, improbably, vary between 1100 and 30,000 (Xhaho and Tandili 2017). And while international organizations and the US State Department consider Albania a hub for trafficking (often in collusion with the police), the Albanian government no longer perceives Albania as a source of organized trafficking. For religious and political reasons prostitution is considered an uncomfortable topic in the 'supply' countries that is best ignored as much as possible.

In the 'demand' countries in Southern and North-Western Europe often the large majority of sex workers consist of migrants. The link between sex work and migration is part of a larger trend in which structurally large income inequalities, limited economic and social opportunities and deeply embedded corruption lead many citizens of low-income countries to migrate to the affluent, mature democracies of Western Europe to improve their employment prospects and to sustain their families at home. Internet, low cost transportation and travel opportunities bring the possibility of migration within the purview of many. Poverty and lack of prospects among women, in combination with injurious gender relations in the home country, has resulted in the feminization of migration; many young women, particularly those with some secondary or higher education, look for better prospects elsewhere (Phillips 2015).

But even in the best of times, migration is a highly ambivalent issue for the high-income welfare states of North-Western Europe. Spurred by right wing political rhetoric, indigenous citizens fear that low-income migrants will abuse the welfare system and displace them on the labor market. Implicitly or explicitly governments grade immigrants according to desirability with respect to the cultural, economic and religious makeup of the country. The moral politics of desirability is expressed in the language with which countries designate immigrants. The most frequently applied labels in policy parlance are "undocumented" and "temporary foreign worker". This framing of people, who in the case of EU and EEA countries are making use of the legal right to free movement of people within the EU, has, as always, strong repercussions for the target group. In Spain for example, the undocumented status of most immigrant women sex workers makes them extremely vulnerable to exploitation and arbitrary behavior by the police (Solano et al. 2017). Discursively, migrants, and sex worker migrants in particular, are considered "cheap", and "disposable", a marginal, substandard class of citizens. Legally, the categories of "illegal" or "temporary", and the laws that give expression to these designations, limit the labor market options of such migrants to the low-skilled, dead-end, poorly protected jobs or to nominal self-employment, and limits their rights and mobility (Cruz 2015, p. 70; Sharma 2015, p. 36). In addition, immigration law is closely allied with criminal law, with criminal justice agencies being assigned with the execution of the law. In the ironic dialectic of public discourse, this entrapment in the criminal justice system and the bottom of the labor market is then held against these migrants, and reinforces their public image as deficient, non-citizens. For migrant sex workers 
the combination of immigration and labor law powerfully shapes their position, possibilities, rights and capacities.

A sixth outcome is the importance of policy implementation. Policy implementation is important in two ways. First, the impact of regulation on the sex trade is largely determined by the practices of local officials. Local officials, often in conjunction with NGOs, design and implement policy instruments that directly impact the work situation of sex workers, brothel owners and managers, and third parties. In some countries (the UK, Italy, Czech Republic) local officials fill a national policy void. We do not mean to say that local measures are always, or necessarily effective, but only that that they have an impact (See below). The second important insight is that these officials and professionals operate in relative autonomy from the national legal frameworks and institutions that formulate policy and make decisions. This results in local policies that may deviate considerably from-even subvert or counteract-national policy. For example the ProstG, the German federal law that attempted to decriminalize prostitution, has hardly been implemented by the regions (Hunecke 2017). On the contrary, in some areas ideologically-driven police officials autonomously introduced mandatory registration of sex workers and raised the minimum age for working in prostitution. In Spain, although prostitution and brothel keeping is legal, cities have introduced punitive measures to clamp down on outdoor sex work. As Solano et al. observe, mechanisms included fines, urban measures, deterrence of sex workers and clients by police patrol presence, immigration documentation controls, and reports of antisocial use of public spaces, and even client criminalization (Solano et al. 2017). In Norway, in an initiative called Operation Houseless, the state encourages landlords and hotels to deny housing and lodging to women suspected of engaging in prostitution (Jahnsen and Skilbrei 2017). In Italy, central government has conferred to local administrations widely expanded powers to adopt and enforce regulations in the field of public security, which the latter use to crack down on street prostitution (Crowhurst et al. 2017). The mechanisms that lead to the deviation of local policy implementation from national law are administrative discretion, regulatory drift and agency capture. Switzerland provides a good example of the negative effects of discretion (and the importance of immigration laws for the regulation of prostitution) when the authors observe that "(f)ighting against human trafficking or exploitation is, indeed, more difficult than punishing illegal stay and work, which leads the authorities to focus on this latter kind of control" (Chimienti and Bugnon 2017). In The Netherlands, regulatory drift-the gradual accumulation of small, instrumental implementation decisions by municipal agencies, mostly under the political radar-was the decisive force in the gradual reversal of the decriminalizing intention of the repeal of the ban brothels to a much more repressive form of regulation (Wagenaar et al. 2017, chap. 3). In Vienna, agency capture, the appropriation of the implementation process by one agency, often, in this case the police, explains the almost exclusive focus on outdoor prostitution in the implementation of a comprehensive policy program (ibid.).

The above policy dynamics apply with even greater force to the relationship between the EU and national and regional administrations. This is not the place to explain the complex mosaic of competences and instruments among the various EU bodies (Outshoorn 2017) but the overarching principle of subsidiarity that specifies that policies should be decided on national or even local level where possible, almost guarantees a loose coupling between the EU and the local level. This pertains even more to issues of criminal law, immigration and national security, which are deeply embedded in, and expressive of, national political and judicial systems. The result is that, in the realm of prostitution policy, the European Parliament either issues non-binding resolutions or approves Directives by the Commission. The Commission and the Council of Ministers can propose Directives and create and fund programs to influence national policy making. Activist commissioners and MEPs (a coalition of Catholics and radical feminists) have used the various EU bodies as a platform for an anti-trafficking agenda. The upshot is that the EU, like the Palermo Protocol, has mostly agenda setting powers, which currently strongly support the neo-abolitionist national discourses of the member states.

In many countries the police play a special role in the discretionary regulation of prostitution. Particularly in countries where prostitution is criminalized or where the cultural acceptance of 
prostitution is very low, the police operates as its de facto regulator. In practice this means the harassment of outdoor sex workers, often through the issuance of arbitrary fines, with the purpose of making prostitution invisible. Some municipalities in the Czech Republic have even hired private security agencies for the purpose of "providing low-key harassment" (Havelkova 2017). In countries where sex workers are criminalized, police corruption in the form of stealing earnings, sexual harassment and physical abuse, is common. The result is a collapse in trust between sex workers and the police, with the former refraining from reporting crimes or harassment by clients. This prejudicial behavior extends to public prosecutors and the courts (Albania, Czech Republic, Romania, Sweden). As Havelkova (2017) reports: "(Sex workers') testimonies are considered unreliable in criminal proceedings and the stereotype of 'prostitute as a bad mother' is used against women by family courts". The combination of mutual distrust between authorities and sex workers and a policy of driving sex workers off the street is particularly detrimental to the position of the latter. Havelkova again: "It pushes them away from public spaces; it has made them less safe; it has contributed to their increasingly distrustful relationships with public authorities; and has done nothing to destigmatize them" (Havelkova 2017).

Finally, what are the outcomes of prostitution policy, both intended and unintended? Although we have no reliable statistics, it is safe to conclude that in terms of influencing the prevalence of prostitution in a country, prostitution policy is largely ineffective. Despite statements, such as in resolution 2014 of the European Parliament, that the Nordic model of client criminalization has effectively reduced prostitution, there is no evidence to support this. Have current repressive approaches to prostitution decreased trafficking? As we have no reliable data on the extent of, or trends in trafficking, there is no conclusive answer to this question. However, based on the best possible estimates outside the remit of the ideology wars around neo-abolitionism, the most likely answer is that in the advanced democracies of North-Western Europe the prevalence of trafficking has been low to begin with (Weitzer 2015; Wagenaar et al. 2017). Perhaps the most obvious conclusion from our research is that all countries under study have-and throughout history, have had-a prostitution market. No matter what legal regime the government adheres to or has adhered to in the past, prostitution is of all times. The number of sex workers in a country might fluctuate, but this is usually the result of extraneous forces outside the purview of policy makers. Even the active closure of sex facilities, such as in the UK and The Netherlands, only seems to displace sex workers or drive them underground. Prohibiting prostitution may have a certain consolatory symbolic value for its proponents, but nowhere does it attain its moral goal of removing prostitution from society or even containing it very effectively. Instead we see in the countries under study that prostitution policy makes a difference in the social position of sex workers. Regulatory measures have an impact on labor relations, workplace conditions, the possibility for starting a business, citizenship status, access to health and social services, taxes and income, housing, and citizenship and human rights. In a few countries this effect is positive. Switzerland is a case in point. Chimienti and Bugnon (2017) state: "The fact (is) that prostitution is legal and the provision of outreach programmes (by both the police and defense associations) have lowered the risks of violence, abuse and exploitation on the Swiss sex market. This helps to strengthen the level of trust in the authorities, and encourages sex workers to report issues of violence, exploitation and mistreatments." And they conclude: independence in combination with legal status "decreases the stress of being caught by the police, but their working conditions are also better: they face fewer health issues and earn more on average". Similar conclusions can be drawn for indigenous sex workers in Portugal, Slovenia, Austria, Germany, and Norway.

Unfortunately, these are exceptions and in most countries policy has a decidedly negative impact on the social position of sex workers. In fact, in countries such as Spain, Italy, the Czech Republic, France, Romania, and Albania, authorities, in particular the police, actively harass sex workers. In most countries harsh immigration laws rob migrant sex workers of their rights. Oliveira (2017) concludes for Portugal, for example, that while indigenous sex workers enjoy a reasonably positive relationship with the police, immigrants are treated as delinquents. In Norway, undocumented migrants have 
trouble accessing health and social services (Jahnsen and Skilbrei 2017). Often non-interference by the state results in a worsening of the situation of sex workers. For example, Dutch authorities steadfastly refused to intervene in labor relation in the sex trade claiming this was a civil law affair. The result is work conditions in brothels that can only be described as exploitative (Altink et al. 2017). Similarly, the International Committee on the Rights of Sex Workers in Europe reports on widespread job insecurity, arbitrary dismissals, the withholding of earnings by brothel owners, the lack of benefits, and hazardous work conditions in sex facilities all over Europe (ICSRE 2016). In most countries, local officials are willing to go much further in tolerating negative work and living conditions for sex workers than national authorities.

Prostitution policy is a domain in which state institutions do not always operate in a righteous way. The different country profiles leave the reader with the impression that sex workers and third parties are often treated as second-class citizens (Wagenaar 2015). The unstated goal of many policies is to make life difficult for sex workers, particularly so for migrant sex workers and the third parties they have enlisted to settle in the country of arrival. The stigma of prostitution (and in the case of migrants the additional stigma of being a migrant) pervades every aspect of public policy, even in countries where prostitution and/or brothels are legalized (Jeffrey 2015). The neo-abolitionist mindset of authorities, pundits and the media only reinforces this dynamic.

The Israeli philosopher Avishai Margalit makes an important distinction in this respect between a civilized and a decent society. "A civilized society" he says, "is a society whose members do not humiliate one another, while a decent society is one in which the institutions do not humiliate people" (Margalit 1996, p. 1). In many of the countries under study, state institutions fail this basic standard of decency towards sex workers (and in many cases their third parties). The focus in the prostitution literature is mostly on rights, but humiliation is an equally important but overlooked and essential value in the government's dealing with its citizens. "Humiliation is any sort of behavior or condition that constitutes a sound reason for a person to consider his or her self-respect injured" (Margalit 1996, p. 9). The problem with humiliation is that, although it might only pertain to a small and peripheral group, it is corrosive to the social relations and moral dignity of a society. Humiliation is contagious (op. cit., p. 32). We either identify with the humiliated person or we do not and accept it, but in both cases we are negatively implicated. Humiliation has an adverse effect on the moral fabric of society. In many European countries (and in the US as well (Chuang 2010; Weitzer 2012)) prostitution policy is affected by a corrosive mixture of deceit about statistics and claims about the extent of trafficking and coercion in prostitution on the one hand, and institutional behavior that is humiliating to sex workers on the other. This has moral implications that far exceed the relatively constricted realm of the sex trade and discussion about what constitutes better or worse public policy. It implies a statement about the kind of society we aspire to be.

\section{Towards an Effective and Decent Regulation of Prostitution}

Is there an alternative to break this century-long deadlock of flawed and ineffective regulation of the sex trade? In this final section I argue that innovative collaborative forms of governance are in principle able to achieve both decent labor rights and work conditions for sex workers and the integration of prostitution in the urban environment. Collaborative governance is conditional upon the presence of viable sex worker advocacy organizations. It is to this that I turn first.

In the absence of trade or professional organizations in the prostitution domain, sex worker advocacy organizations (SWAs) fill this gap (Wagenaar et al. 2017, chap. 6). Although there is a considerable literature on SWAs, ${ }^{8}$ much of it focuses on the USA or the Southern Hemisphere. Almost nothing has been written about Europe, where SWAs have been active for over a century (Stevenson and Dziuban 2017). SWAs are self-organizations "where sex workers are at the center of the

8 See Stevenson and Dziuban (2017) for helpful references. 
decision making processes, the development of organizational doctrines and the determination of the course of action" (Stevenson and Dziuban 2017). According to the authors, more than 40 sex worker organizations are currently active in Europe. They are self-organizing collectives, unions or NGOs. They engage in collective action to protest wrongs, argue for the improvement of working conditions, counter stigma and draw attention to gross injustice. In an antagonistic policy environment, social protest and pressure group activities that aim at the improvement of general civil, political and human rights are the tactics of choice for SWAs (Gall 2014, p. 224). The key demand of sex worker advocacy is the "recognition of sex work as a legitimate form of livelihood and income generating activity" (Stevenson and Dziuban 2017). Some sex worker advocacy organizations also provide direct services, such as legal advice, medical services or the distribution of condoms, in some cases on the basis of contracts with state agencies.

What is much less common is the involvement of sex worker advocacy organizations in the design and implementation of public policy. An illustrative example of this is the relationship of the Dutch sex worker advocacy group the Rode Draad (Red Thread) with the city of Rotterdam. In 1999 the Rode Draad was invited to become a participant of the municipal 'Advisory Commission Prostitution' in that city. Members of the Commission, each representing an organization with some authority and mandate in the domain of local prostitution policy, were the police, the Tax Authority, social work, public health, city administrators, and the Rode Draad. The Commission met once a month and its tasks were to formulate policy advice, to design policy solutions, to monitor the situation 'on the ground' in the city, and to signal instances of trafficking and exploitation. For example, the Rode Draad had observed that illegal, coerced prostitution took place in Turkish coffee houses in the city. This is an excellent example of what Bourgon calls "adaptive capacity", the ability to react swiftly and effectively to unexpected emerging situations (Bourgon 2011, p. 60). Almost adventitiously the Commission achieved a considerable amount of policy coordination, another instance of the adaptive and resilient capacity that such a collaborative arrangement brings to the governance system (Bourgon 2011, p. 60). The Rode Draad participated in the Commission from 1999 to 2008. To make this possible it received a small subsidy and the use of an office from the city.

This is an example of what is known in policy theory as "collaborative governance". Collaborative governance is a mode of governance in which public agencies engage with various stakeholders to jointly deliberate about public problems (Ansell 2011, p. 167). It forms an alternative to three traditional forms of governance common in European prostitution policy: adversarial politics in which the party in power makes decisions by imposing its will on minority parties, coalition politics, where parties, none of which can expect to gain an outright majority, make decisions by bargaining among themselves, and managerial governance, in which management processes function as means for collective problem solving and service delivery. Collaborative governance differs from the more generic term 'governance' in that it requires more stringent, more demanding standards of working together. As the example of the Rode Draad shows, collaborative governance enhances governance capacity, enables administrative coordination, improves information gathering, increases effectiveness, and unlocks creative potential and "thinking out of the box" (Innes and Booher 2010). The design requirements for successful collaborative governance are the following (Ansell and Gash 2008; Innes and Booher 2010; Wagenaar et al. 2017). First, it is essential that actors from civil society who are affected by the policy, who are stakeholders in other words, are involved in the governing arrangement. This applies particularly to marginal or peripheral actors, such as sex workers, and in many cases, residents. Second, the collaborative arrangement needs to be authoritative. That is, it must be aimed at, and have the mandate for, decision-making. Third, the collaborative arrangement must have a formal and not a casual character. In practice this means that government agencies sometimes fund stakeholder organizations, such as sex workers organizations, to make it possible for them to spend time on working with government agencies, to take part in training to acquire skills such as chairing a meeting or monitoring complex contracts, and as a token of their recognition as valued partners in the desired governance arrangement. And fourth, the participants in collaborative governance arrangements 
have to be willing to engage in "authentic dialogue". Authentic dialogue is a technical term that signifies a process of communication that observes basic requirements of accuracy, comprehensibility, sincerity, and legitimacy (Innes and Booher 2010, pp. 97-99). Authentic dialogue can only be achieved in situations of face-to-face dialogue.

At first blush this may seem as impossible demands in the often deeply contested domain of prostitution policy. The levels of trust this kind of collaboration entails simply do not exist among stakeholders in prostitution. Moreover, in situations in which the dominant party has been willing to suspend common norms of decency, the odds for collaboration in good faith are even less promising. This objection can be countered with two empirical observations. First, collaborative arrangements emerge precisely in situations where conventional policy making has persistently failed. As (Ansell and Gash 2008, p. 544) observe: “Collaborative governance has emerged as response to the failures of downstream implementation, and to the high cost and politicization of regulation. It has developed as an alternative to the adversarialism of interest group pluralism and to the accountability failures of managerialism (especially when the authority of experts is challenged)." These collaborative initiatives have been created in areas such as schools, community policing, land use planning, community health, and environmental policy making. In other words, collaborative initiatives have emerged precisely in situations of stubborn conflict, where the adversaries view each other with mutual distrust, hurt and anger.

The second argument is that collaborative governance has been shown to work in prostitution policy. ${ }^{9}$ The above example of the Rode Draad is one, and did indeed follow a period where the usual managerial and coalition politics in Rotterdam had failed to find a solution to the city's prostitution issues. Other successful cases can be found in Vancouver and New Zealand (Abel et al. 2010; Johnson 2015). In fact, our research shows that the success of New Zealand's decriminalization policy should be attributed to the involvement of the New Zealand Prostitutes Collective in the design and implementation of policy making and in providing moral leadership on the issue of prostitution (Wagenaar et al. 2017, p. 253). Although we need more research to understand what makes these cases effective, these examples of successful collaborative governance suggest an escape from the failing ideology-driven, adversarial policy approaches that most European countries have followed in the last century and a half with regard to regulating prostitution.

To conclude: in this paper I present a unique, robust body of evidence that shows that there is a repressive bias in much prostitution policy in the developed world. A combination of stigma, moral controversy, the dominance of an ideology that conflates prostitution with trafficking, and misgivings about lowly skilled immigrants, leads authorities to adopt a strategy of controlling sex workers and curtail visible forms of prostitution. However, this results in the ignoring of the widespread labor exploitation in sex facilities all over Europe. I argue for a strategy of collaborative governance with sex worker advocacy organizations to attain an effective and humane prostitution policy.

Acknowledgments: I thank and acknowledge COST Action IS1209 Prospol and COST for providing the scientific and financial support to the project on which this article draws.

Conflicts of Interest: The author declares no conflict of interest.

\section{References}

Abel, Gillian, Lisa Fitzgerald, Catherine Healy, and Aline Taylor, eds. 2010. Taking the Crime out of Sex Work. New Zealand's Sex Workers' Fight for Decriminalisation. Bristol: Policy Press.

Altink, Sietske, Ilse van Liempt, and Marjan Wijer. 2017. The Netherlands. In Assessing Prostitution Policies in Europe. Edited by Synnøve Økland Jahnsen and Hendrik Wagenaar. Abingdon: Routledge, in press.

9 For a more extensive argument on the possibility of collaborative governance in prostitution, see (Wagenaar et al. 2017, chap. 6). 
Ansell, Christopher. 2011. Pragmatist Democracy. Evolutionary Learning as Public Philosophy. Oxford: Oxford University Press.

Ansell, Christopher, and Gash Allison. 2008. Collaborative governance in theory and practice. Journal of Public Administration Theory and Practice 18: 543-71. [CrossRef]

Asmar, Melanie. 2014. Sex Trafficking and Sporting Events Linked? Arrest Records Raise Doubt. Available online: http:/ / www.westword.com/content/printView/5848537 (accessed on 26 April 2017).

Bernstein, Elizabeth. 2010. Militarized Humanitarianism Meets Carceral Feminism: The Politics of Sex, Rights and freedom in Contemporary Trafficking Campaigns. Signs 36: 45-71. [CrossRef] [PubMed]

Bourgon, Jocelyne. 2011. A New Synthesis of Public Administration. Serving in the 21st Century. Quebec: McGill-Queen's University Press.

Chimienti, Milena, and Géraldine Bugnon. 2017. Switzerland. In Assessing Prostitution Policies in Europe. Edited by Synnøve Økland Jahnsen and Hendrik Wagenaar. Abingdon: Routledge, in press.

Chuang, Janie A. 2010. Rescuing trafficking from ideological capture: Prostitution reform and anti-trafficking law and policy. The University of Pennsylvania Law Review 158: 1655-728.

Corbin, Alain. 1990. Women for Hire. Prostitution and Sexuality in France after 1850. Cambridge: Harvard University Press.

Crowhurst, Isabel, Patrizia Testaì, Cesare di Feliciantonio, and Guilia G. Geymonat. 2017. Italy. In Assessing Prostitution Policies in Europe. Edited by Synnøve Økland Jahnsen and Hendrik Wagenaar. Abingdon: Routledge, in press.

Cruz, Katie. 2015. Centring the State in our Critiques of Trafficking. In State and the Law. Beyond Trafficking and Slavery Short Course. Edited by Prabha Kotiswaran and Sam Okyere. London: Open Democracy, vol. 3, pp. 68-71.

Danet, A. 2017. Romania. In Assessing Prostitution Policies in Europe. Edited by Synnøve Økland Jahnsen and Hendrik Wagenaar. Abingdon: Routledge, in press.

Davidson, Julia O'Connell. 2006. Will the real sex slave please stand up. Feminist Review 83: 4-22. [CrossRef]

Dodillet, Susanne, and Östergren Petra. 2013. The Swedish Sex Purchase Act: Claimed Success and Documented Effects. In Final Report of the International Comparative Study of Prostitution Policy. Edited by Hendrik Wagenaar, Sietske Altink and Helga Amesberger. The Hague: Platform 31.

Doezema, Jo. 2010. Sex Slaves and Discourse Masters. The Construction of Trafficking. London: Zed Books.

Gall, Gregor. 2014. Collective interest organization among sex workers. In Negotiating Sex Work. Unintended Consequences of Policy and Activism. Edited by Carisa R. Showden and Samantha Majic. Minneapolis: University of Minnesota Press.

Gibson, Mary. 1986. Prostitution and the State in Italy, 1860-1915. New Brunswick: Rutgers University Press.

Goggin, Malcolm L. 1986. The “Too few Cases/Too many Variables" Problem in Implementation Research. The Western Political Quarterly 39: 328-47. [CrossRef]

Havelkova, Barbara. 2017. The Czech Republic. In Assessing Prostitution Policies in Europe. Edited by Synnøve Økland Jahnsen and Hendrik Wagenaar. Abingdon: Routledge, in press.

Hunecke, Ina. 2017. Germany. In Assessing Prostitution Policies in Europe. Edited by Synnøve Økland Jahnsen and Hendrik Wagenaar. Abingdon: Routledge, in press.

International Committee on the Rights of Sex Workers in Europe. 2016. Exploitation. Unfair Labour Arrangements and Precarious Working Conditions in the Sex Industry. Amsterdam: ICRS. Available online: http:/ / www.sexworkeurope. $\mathrm{org} /$ news/general-news/may-day-icrse-launches-community-report-exploitation-sex-industry (accessed on 26 April 2017).

Innes, Judith E., and David E. Booher. 2010. Planning with Complexity. An Introduction to Collaborative Rationality for Public Policy. Abingdon: Routledge.

Ison, Ray. 2010. Systems Practice: How to Act in a Climate-Change World. London: Springer.

Jahnsen, Synnøve Økland, and May-Len L. Skilbrei. 2017. Norway. In Assessing Prostitution Policies in Europe. Edited by Synnøve Økland Jahnsen and Hendrik Wagenaar. Abingdon: Routledge, in press.

Synnøve Økland Jahnsen, and Hendrik Wagenaar, eds. 2017. Assessing Prostitution Policies in Europe. Abingdon: Routledge, in press.

Jeffrey, Leslie A. 2015. Cave! Hic Dragones: Negotiating the Contradictory Pressures of Sex Work Policy Making: Lessons for Canadian Policy-Makers. Paper presented at the Second International Conference on Public Policy, Milan, Italy, July 1-3. 
Johnson, Genevieve Fuji. 2015. Governing sex work: An agonistic policy community and its relational dynamics. Critical Policy Studies 9: 259-77. [CrossRef]

Jones, Gareth Stedman. 2013. Outcast London: A Study in the Relationship between Classes in Victorian Society, 2nd ed. London: Verso Books.

Kempadoo, Kamala. 2012. Introduction. Abolitionism, criminal justice, and transnational feminism: Twenty-firstcentury perspectives on human trafficking. In Trafficking and Prostitution Reconsidered. New Perspectives on Migration, Sex Work, and Human Rights, 2nd ed. Edited by Kamala Kempadoo. Boulder: Paradigm Publishers, pp. vii-xlii.

Landman, Todd. 2000. Issues and Methods in Comparative Politics: An Introduction. Abingdon: Routledge.

Margalit, Avishai. 1996. The Decent Society. Cambridge: Harvard University Press.

Oliveira, Alexandra. 2017. Portugal. In Assessing Prostitution Policies in Europe. Edited by Synnøve Økland Jahnsen and Hendrik Wagenaar. Abingdon: Routledge, in press.

Outshoorn, Joyce. 2017. European Union and Prostitution Policy. In Assessing Prostitution Policies in Europe. Edited by Synnøve Økland Jahnsen and Hendrik Wagenaar. Abingdon: Routledge, in press.

Pheterson, Gail. 1996. The Prostitution Prism. Amsterdam: Amsterdam University Press.

Phillips, Nicola. 2015. What has forced labour to do with poverty? In Forced Labour in the Global Economy Short Course. Edited by Genevieve LeBaron and Neil Howard. London: Open Democracy, vol. 2, pp. 14-27. Available online: https:/ / www.opendemocracy.net/beyondslavery (accessed on 26 April 2017).

Sanders, Teela, and Rosie Campbell. 2014. Criminalization, Protection and Rights: Global Tensions in the Governance of Sex. Criminology and Criminal Justice 14: 535-48. [CrossRef]

Sharma, Nandita. 2015. Anti-Trafficking: White-Wash for Anti-Immigration Programs. In State and the Law. Beyond Trafficking and Slavery Short Course. Edited by Prabha Kotiswaran and Sam Okyere. London: Open Democracy, vol. 3, pp. 36-40.

Solano, Mariola B., Alina Danet, and Joan C. M. Cerdà. 2017. Spain. In Assessing Prostitution Policies in Europe. Edited by Synnøve Økland Jahnsen and Hendrik Wagenaar. Abingdon: Routledge, in press.

Stevenson, Luca, and Agata Dziuban. 2017. Silent No More: Self Determination and Organisation of Sex Work in Europe. In Assessing Prostitution Policies in Europe. Edited by Synnøve Økland Jahnsen and Hendrik Wagenaar. Abingdon: Routledge, in press.

Stone, Deborah. 1997. Policy Paradox. The Art of Political Decision Making. New York: W. W. Norton \& Company.

Vance, Carole S. 2011. States of Contradiction: Twelve Ways to Do Nothing about Trafficking While Pretending to. Social Research-An International Quarterly 78: 933-48.

Wagenaar, Hendrik. 2011. Meaning in Action: Interpretation and Dialogue in Policy Analysis. Armonk: M. E. Sharpe. Wagenaar, Hendrik. 2015. Governance-Driven Conflict: Policy, Reason of State and Authoritarian Governmentality. In Conflict in the City: Contested Urban Spaces and Local Democracy. Edited by Enrico Gualini, Marco Allegra and João Morais Mourato. Berlin: Jovis Verlag, pp. 112-32.

Wagenaar, Hendrik. 2017. Introduction. In Assessing Prostitution Policies in Europe. Edited by Synnøve Økland Jahnsen and Hendrik Wagenaar. Abingdon: Routledge, in press.

Wagenaar, Hendrik, Helga Amesberger, and Sietske Altink. 2017. Designing Prostitution Policy: Intention and Reality in the Sex Trade. Bristol: Policy Press.

Wagenaar, Hendrik, and Sietske Altink. 2012. Prostitution as Morality Politics or Why It Is Exceedingly Difficult To Design and Sustain Effective Prostitution Policy. Sexuality Research and Social Policy 9: 279-97. [CrossRef]

Walkowitz, Judith. 1980. Prostitution and Victorian Society: Women, Class and the State. Cambridge: Cambridge University Press.

Weitzer, Ronald. 2007. The social construction of sex trafficking: Ideology and institutionalization of a moral crusade. Politics \& Society 35: 447-75.

Weitzer, Ronald. 2012. Legalizing Prostitution: From Illicit Vice to Lawful Business. New York: New York University Press. Weitzer, Ronald. 2015. Human trafficking and contemporary slavery. Annual Review of Sociology 41: 223-24. [CrossRef] Xhaho, Armela, and Alma L. Tandili. 2017. Albania. In Assessing Prostitution Policies in Europe. Edited by Synnøve Økland Jahnsen and Hendrik Wagenaar. Abingdon: Routledge, in press.

(C) 2017 by the author. Licensee MDPI, Basel, Switzerland. This article is an open access article distributed under the terms and conditions of the Creative Commons Attribution (CC BY) license (http:/ / creativecommons.org/licenses/by/4.0/). 